\title{
The free spirit: spiritualism meanings by a Nursing team on psychiatry
}

\author{
O espírito solto: significados de espiritualidade por equipe de enfermagem em psiquiatria \\ El espíritu suelto: significados de espiritualidad por equipo de enfermería en psiquiatría
}

\begin{abstract}
Gabriel Lavorato-Neto', Larissa Rodrigues', Egberto Ribeiro Turato", Claudinei José Gomes Campos'
'Universidade Estadual de Campinas, Faculty of Nursing, Postgraduate Program in Nursing. Campinas, São Paulo, Brazil. "Universidade Estadual de Campinas, Medical Sciences University, Medical Psychology and Psychiatry Department. Campinas, São Paulo, Brazil.
\end{abstract}

How to cite this article:

Lavorato-Neto G, Rodrigues L, Turato ER, Campos CJG. The free spirit: spiritualism meanings by a Nursing team on psychiatry. Rev Bras Enferm [Internet]. 2018;71(2):280-8. DOI: http://dx.doi.org/10.1590/0034-7167-2016-0428

Submission: 11-04-2016

Approval: 04-12-2017

\section{ABSTRACT}

Objective: To analyze the meanings attributed by nursing professionals in psychiatry to spirituality and its relationship with care. Method: Clinical-qualitative, with appreciation of symbolic meanings. We interviewed 18 individuals for a semi-structured script of open questions and the data were analyzed in the light of psychoanalytic hermeneutics. The discussion was undertaken with the overlap of understanding of the sacred symbol, psychological and the meaning of life. Results: Different spiritualities are interposed by personal restlessness and the experience of transience. Spirituality aids in social functions, personal balance and commitment to endure the anguish of transience. Among professionals, it has been shown as an ethical-combative attitude to evil forms, but there is a restriction in dealing with patients' spirituality. Final considerations: The meanings pointed to the limits of human reason, resembling caregivers and patients in subjective conditions by which they avoid spirituality in psychiatry. It is suggested that spiritual attention be given to professionals.

Descriptors: Spirituality; Psychiatric Nursing; Mental Health; Holistic Nursing; Religion and Psychology.

\section{RESUMO}

Objetivo: Analisar os significados atribuídos por profissionais de enfermagem em psiquiatria à espiritualidade e sua relação com o cuidado. Método: Clínico-qualitativo, com apreciação dos significados simbólicos. Entrevistou-se 18 sujeitos por um roteiro semiestruturado de questões abertas e os dados foram analisados à luz da hermenêutica psicanalítica. A discussão se empreendeu com a sobreposição do entendimento do símbolo sagrado, psicológico e do sentido da vida. Resultados: Distintas espiritualidades se interpõem pela inquietação pessoal e a experiência com a transitoriedade. A espiritualidade ajuda nas funções sociais, no equilíbrio pessoal e no empenho em suportar as angústias da transitoriedade. Entre os profissionais, se mostrou como uma atitude ético-combativa às formas maléficas, mas há restrição em lidar com a espiritualidade dos pacientes. Considerações finais: Os significados apontaram para os limites da razão humana, assemelhando cuidadores e pacientes em condições subjetivas pelas quais evitam a espiritualidade em psiquiatria. Sugere-se atenção espiritual para os profissionais.

Descritores: Espiritualidade; Enfermagem Psiquiátrica; Saúde Mental; Enfermagem Holística; Religião e Psicologia.

\section{RESUMEN}

Objetivo: Analizar los significados atribuidos por profesionales de enfermería en psiquiatría a la espiritualidad y su relación con el cuidado. Método: Clínico-cualitativo, con estimación de los significados simbólicos. Fueron entrevistados 18 sujetos por un itinerario semiestructurado de preguntas abiertas y los datos analizados a la luz de la hermenéutica psicoanalítica. La discusión se emprendió con la superposición del entendimiento del símbolo sagrado, psicológico y del sentido de la vida. Resultados: Distintas espiritualidades se interponen por la inquietud personal y la experiencia con la transitoriedad. La espiritualidad ayuda en las funciones sociales, en el equilibrio personal y en el empeño en soportar las angustias de la transitoriedad. Entre los profesionales se mostró como una actitud ético-combativa a las formas maléficas, pero hay restricción en trabajar con la espiritualidad de los pacientes. Consideraciones finales: Los significados señalaron los límites de la razón humana, asemejando 
cuidadores y pacientes en condiciones subjetivas por las que evitan la espiritualidad en la psiquiatría. Se sugiere atención espiritual para los profesionales.

Descriptores: Espiritualidad; Enfermería Psiquiátrica; Salud Mental; Enfermería Holística; Religión y Psicología.

\section{CORRESPONDING AUTHOR Gabriel Lavorato NetoＥ-mail: lavorato.neto@gmail.com}

\section{INTRODUCTION}

In psychiatric Nursing care, the dimension of spirituality (1) in the holistic demand for human needs has been shown to be a complex and contradictory task, despite being better received in the general health setting ${ }^{(2)}$. The theoretical tendency is to promote the expansionist stance of attention to this dimension, and to warn about its limits of research and education ${ }^{(3-4)}$.

In psychiatric nursing studies, spirituality figures as an elementary human need, with a deep function in people's lives ${ }^{(5-6)}$, linked to the promotion of well-being and the establishment of transcendental connections with the sacred, with the deep being I inner), and with ordinary everyday life. This function modulates the experience of symbolic significance of the purpose and events of

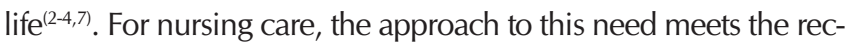
ommended holistic and humanized parameters ${ }^{(2-3,8-11)}$. Although studies point to the value of meeting these needs, they also contradict the possibility of their neglect of psychiatric care ${ }^{(3-4,7,12-13)}$.

A crucial omission in studies is: what is the function of the meaning that professionals attribute to spirituality, its relationship to the experiential process by which it builds it, and its unfolding of care $^{(8)}$. Our purpose with this study is to verify this lapse, realizing that considering spirituality from meanings refers to describing the symbolic constructions of professionals, and then reflecting them in the light of Paul Ricoeur's theoretical framework ${ }^{(14-16)}$ Freud $^{(17-18)}$ and Frank $\left.\right|^{(19-20)}$, traditionally respected authors in the understanding of health phenomena, and thus allow a superscript understanding of the symbolic value obtained in the analysis of the meanings studied.

\section{METHOD}

\section{Ethical aspects}

The ethical prerogatives were assured, according to the Ethics Research Committee's opinion. The individuals consented to participate in the research through the signing of the Informed Consent Term.

\section{Type of study}

We adopted the clinical-qualitative method, a contribution of the qualitative designs intended for research in health scenario $^{(21)}$. Prioritizing the interpretation of symbolic meanings, this method requires the researcher, the main instrument of data collection and analysis, to value an "existentialist, clinical and psychoanalytic" attitude ${ }^{(21)}$ in the field, in the analysis, and in the production of the results.

\section{Study scenario}

The study was conducted in a psychiatrist ward in a tertiatry hospital in São Paulo, countryside.

\section{Data source}

The unit's nursing staff population was 22 members, all were intentionally invited to participate in the study, but four declined in attendance. The sample was closed with 18 individuals, composed of 10 women and 8 men; 6 evangelicals, 9 Catholics, 3 Spiritists, characterizing a predominantly Christian tradition in the study scenario; the nursing work time was between 1 year and 9 months and 32 years; 11 of the 18 professionals had a college degree, but only 5 were enrolled in higher-level careers, the rest working at a technical level. Each individual received a codename inspired by philosophical and mythological figures of antiquity.

\section{Data collection}

The procedures ${ }^{(21)}$ to obtain the data were: familiarization with the field; the collection of data through a script of semi-structured interviews of open questions and previously tested in a place outside the field; the recording of relevant information from the observation of the field researcher and interviews. The interview script, semistructured with open questions, as well as demographic and functional data, investigated the nature of spirituality and was previously tested with outpatient psychiatric nurses and in a place outside the field.

The collection took place from August / 2015 to January / 2016. The interviews were recorded in MP3, with an average duration of 25 minutes, and subsequently transcribed.

\section{Data analysis}

Guided by the hermeneutic theory of Paul Ricoeur ${ }^{(14-15)}$ established from his reading of Freud, which claims that "interpretation is the intelligence of the double meaning"(15), the analysis occurred from successive ${ }^{(21)}$ of the interviews, in order to apprehend symbolic contents: symbol is "any structure of signification from which a direct, primary and literal meaning, designates by addition another indirect, secondary and figurative meaning, which can only be seized through the

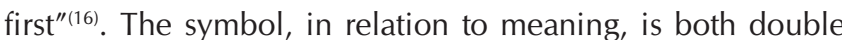
and multiple ${ }^{(15)}$. Therefore, the researcher focused on finding in the data corpus, the contradictory, complementary or remontantes axes, in relation to signification, expression and designation ${ }^{(15)}$, manifest and latent ${ }^{(15)}$, especially those that had the "indirect expressions borrowed from the everyday sphere of experience ${ }^{\prime \prime(16)}$. The logic of Freudian meaning and interpretation was respected, recognizing the multiple sense that occurs in the individual's divisions, when formulated between psychic levels that validate the contradictory, without the possibility of negation or temporality, and governed by formations that make up the satisfaction of the demands of desire ${ }^{(22)}$.

When the readings were complete, the researcher chose and organized in spreadsheets the units of speech in which 
he understood that the multiple sense was transparent. Organized these units of expression, they received a name, usually extracted from the expression itself, and were logically grouped into the categories: The Development of Spirituality; The Function of Spirituality in Personal Experience; Spirituality in Nursing and Psychiatric Care Faith, Belief, Religion; Spirituality and Conflict. These categories are presented in the following results, so that readers share the "sense link"(21) with the individuals and correlate them to their own context.

\section{RESULTS}

Condensed on the sign of spirituality are the elements of meaning of life, belief, faith and religion. It expresses the ethical and metaphysical precedents between good and evil in conducting to life. It is transcribed into ritualistic elements and sacred objects. In it are also condensed contradictions about the expected effects of spirituality: What happens in the pathological sphere of madness resembles the normative states of life when faced by spiritual perspective.

The spirituality described here speaks of experience as the crossing of moments in which it becomes necessary to suspect reason or suppress it. This function resembles madness, but is softened in the reaches of its effects. The categories listed below demonstrate this phenomenon, with their respective subcategories designated by alphabetic symbols.

\section{The development of spirituality}

It is the emergence of spirituality in life, its constitution, the core of its operations, and the elements it brings together. It reflects the dual nature that involves the mental health caregiver: his life and mental health, and the engagement of the effects of his work on his life.

\section{a. The spiritual restlessness}

It is when the perception about oneself and life implies the sensation of anguish that promotes restlessness and the search for answers, or knowledge, that focus on the experience and offer the solution of the mysteries that surrounds it. Examples are the concerns about undeserved suffering, about death, about the transience of happiness. Such unrest also undermines other elements of spirituality such as faith and belief, conception of God, and imply a change of religious choice and posture toward life.

[...] We only remember God more, we only come closer to God's feet, seeing the side of spirituality, when you go through some kind of suffering. (Aristotle)

[...] then, today I'm going through a very good situation ... a very complicated personal situation like this ... that I got married in 2010, right? And I'm currently divorcing, right? so ... it's ... I've been approached again, even asking for it ... (Achilles)

\section{b. The hospital starts spiritually}

There is a nascent spirituality in the hospital work environment. If there is spiritual initiation, the hospital promotes this symbolic rite of passage which results in the individual having a self-judgment of readiness to assume his other social functions. The hospital world promotes connection with the sacred, which reformulates the life of the caregiver who lives in it. The excerpt from the following speech, elucidates this system of apprehension, and shows the phases that he attributes to his condition at the beginning of his career in psychiatric hospital, and the subsequent evolution of its professional and social functioning, attributing this progress to the work that the hospital has performed in it.

[...] We knew you were coming back [to work], you did not fulfill everything you had to do here yet, we knew you were going back to the hospital yet. (Hephaestus)

These words were spoken to him by his co-workers upon his return to the hospital from which he had left. With them they express what happened to him in that hospital environment, where he ceased to be a subversive young man and became an adult and a professional. When he quotes colleagues, he evades the words "to work," he returned to the hospital, not to work in the hospital. The meaning is merging with the use it makes for those returning to continue a treatment. As it is the case of this individual and another below mentioned.

\section{[...] Inside the hospital you see people dying ... suffering ... coming in one way and leaving another, right. So you start to see that emotionally speaking, spiritually speaking, there's something that's going on, it's happening, it's not ... I live it like it's a very nice mission that I'm fulfilling, that I'm living, right? (Crispo)}

\section{c. There is a spirituality that forms among the many: The many sources of spirituality}

There is a distinction between private and cultural discourse on spirituality. There are different sources of spirituality. The individual forms his spirituality by combining a particular form among the many existing sources.

\section{[...] at least for me, it is ... the main basis of sustenance for, for ... for all the circumstances of life, if it is spirituality that I understand. (Aristotle)}

\section{[...] Spirituality in psychiatry are you talking about? (Rhodopis)}

This formation inspires and placates him the restlessness that moves him in his spiritual quest. Often, the novelty motivates him to reinvestigate his questions and, basically, the conviction is not pure. There are divisions and ideas that always come to you from other sources.

\section{It's someone who inspires}

Many people have as a source of spirituality the inspiration in other people. The mother, or the one who plays her part, is an important and striking element in this sense, like the aunt who welcomes the disoriented individual at home:

[...] I have an aunt ... I started to live with her a lot and she gave me the knowledge and I found myself in what she told me. (Esculápia) 
[...] Well, at first I was born. So it was a choice of my parents, but over the years it's my choice. I like. (Philosophine)

This situation reflects an alliance between the individual and his admired one, crossed by the spiritual choice that is constituted in him. The alliance brings together elements of the common spirituality, adopted by a process similar to that by which a child recognizes and adopts his parents, a phenomenon that can describe one of the conditions of religious election.

\section{The role of spirituality in personal experience}

The meanings given to spirituality depend on how it influences the way individuals behave in life. Spirituality has the function of enabling the individual for the performance of social roles and imprinting constancy, and for this, it is necessary to use sacred practices that strengthen him for this performance.

\section{a. The performance of social functions}

Spirituality is tied to family roles, work, and interpersonal relationships. Here we note the antagonism and the multiple senses between being good and bad, doing good or bad, or simply persevering in the necessary task, playing the social against the circumstance that prevents desire. It is by the presence of the greater sacred element, with which the individual tells, that he can devote himself to the transient moment, unused, and unwanted, to maintain the hope of perpetuating his targets. An example is the interviewee Rhodopis' expression: "everything praying and God acting, working with me too". In the first sense, God is acting in the situation and in the individual - he struggled for the board of the institution to change its functional occupation to the nursing, once it had completed the formation for the area in the superscript sense, it continued in the same undesired post while the relocation did not happen.

[...] If I am well, spiritually, if I am well, let me say; I can do a good job, be a good son, a good father, a good husband. (Aristotle)

It is the action of spirituality that results in tranquility for the chores, to ensure tranquility in the agitation of routine, so that the notion of having "self-pity" or self-pity is unnecessary, it is enough for God hospital work, in which all suffer together.

\section{b. Maintain personal balance}

To balance is to equate the opposition between the forces of the fateful and the ideal; between personal strength and force majeure; or it is preserving and not shaking. Balancing requires something greater than yourself, something that "can lead the person", therefore, beyond its minor state. The person split up in the many positions needs a point of equilibrium that satisfies the multiple forces satisfactorily, this is the place of the beyond, of the greater force, the beyond itself.

[...] It's what gives me balance, especially for the profession. Balance, emotion, understanding ... for problems, mainly. (Esculápia)
The split breaks down and reduces the inner being by partitioning it; the balance softens the pressure between the split points.

\section{c. Maintenance of practices for the sacred and attitudes towards life}

Concerning the process of spiritual formation of these individuals, sacred practices were revealed: prayers, rituals, amulets, actions for which they think to impel on the common and profane plane a manifestation of the sacred plane. These particularized practices, although inherited from the religious tradition that integrates the individual, are appropriations of the symbolic construction, and reflect the interlocutions lived by the individuals: the practice of charity that makes the sensibility "beat", of the connotative expression to call, as the knocking at the door, but that in denotation, is to attack. In the context, it is also expressly to snatch - to take off and to take the force, when the sensibility beats, the individual is taken, dominated by that force that attacks him, it is necessary to respond by doing something that relieves him of the pain of seeing the other in need. The practice of charity as an element of his disposition to the sacred relieves both of them by identification.

[...] oh ... I am very charitable, the sensitivity beats ... I think that it snatches some of it. (Equestro)

Carrying an amulet - a third, "missanga", as he calls it, concealing his bearing beneath the sleeve of his T-shirt on the forearm of his strong side during the vestibular test gives hope of getting help to pass him. "Passing" is the enunciation of all the embarrassing moment of the circumstances just lived by the individual, a proof, and his will is that the proof of the scarcity finish, and begin the training time that will help him to improve his condition of life. The amulet is nothing, but it is the memory of someone who looks at the individual at the moment of proof, whether God or the mother who gave it, it means encouragement that gives spirit. I remember that madly puts you in the movement to make happen what seems impossible.

[...] I took this string-type bead and I was ashamed of it ... I was going to do the tests and started putting that bead on the arm, the forearm like that, on the top ... and covered with the so ... and I had, I started, to get a very crazy thing like that ... to talk to that, not with the beads, but to talk to God, to look, that whole thing. (Achilles)

Amulet and gratitude combine the commitment and the efforts that are represented in the practices and intermediate the extraordinary support in the ordinary madness to perform. This is the sense of the practice of thanking, which went awry to seek alternative ways expressed in another interview.

\section{d. To save}

Saving is the antonym of losing and is a spiritual concern at the heart of various religious traditions. The nursing team in psychiatry also deals with a symbolic way of saving the patient. This theme for the team builds on personal experience, and then applies to coexistence in the provision of care in mental health care practices. 
In the symbolic meanings attributed by the team, the lack, the illness, and the experience of contemplating death surpasses the material resource, it lacks content - to lack is to be empty of interior content, it is despair. Facing the disease is also facing the lack of health, and financial resources that run out with health (and consequently, treating the disease). The disease brings hunger and bitterness and we must seek forms of love to face losing. As for mourning, it is lack without solution, it is lacking who has gone forever, the only possible solution is the joke: "Enter the sect", which translates the cacophony, "accept that improves". To save is to revert to material and personal losses (fill the void of lack of content), fill the soul with love, buffer the pain of goodbye without filling its core.

[...] I saw that this path, that belief, could save many people ... In the matter of needy family, they helped both in the feeding part, as in the part of spirit, that they had no content [...] I saw that this way, that belief, could save many people ... In the matter of needy family, they helped both in the feeding part, as in the part of spirit, that they had no content. (Spartakus)

In relation to the environment and the practice of nursing care, religious salvation is contradictory. It becomes a serious problem because it causes rigidity and disorganization of the personality of the patients.

[...] There are cases of, from families, relatives who are religious comes here with bible and the patient when he sees the bible, he wants to rip the bible. It's very, very interesting. Does not match. (Filofrósine)

The team believes that the religious attempt to save the patient is to lose it to madness. What is possible is to save their bodies by giving them a slipper to save their bare feet - the needy; or do what is possible on the professional side in order to manage your body-directed therapy - try to save them from the disease.

\section{Spirituality in nursing and psychiatric care}

The nature of care in psychiatry and the presence of spirituality in it, earns its own category, as well as the questions already mentioned about the function of saving. There is a contradiction in the designation of the individuals about the nature of the psychiatric illness and the involvement that they (not) maintain with that nature. They suspect that the disease is completely spiritual in nature. The symbolic meaning took place in the terrain of strangeness, the inexplicable, the hybrid, the suspicious and the frightening. The organic, psychological, and social element has never been evaded by the team's talk, yet the participants have let it escape that the environment is heavy, the nature of work is, by metaphorical implications, madness.

\section{a. The suspicion on the nature of the psychiatric illness}

What is psychiatric (or spiritual) illness? The individuals of this research unanimously revealed a single certainty: they have doubts about the question and feel divided about the answer. Of the explanation they have to offer, suspicion weighs heavily.
[...] 'Wow, my creeds are afraid to go in there. Wow, he's in ... He's possessed', right ... So ... The other technician looked at me and said, 'Mine, he is psychotic 'né ... This barrier, this thing that we work is very crazy né [the crazy thing brings together being and being possessed and being psychotic, and crazy is there is no reason between the sides]. (Achilles)

[...] Well, for me psychiatry has everything to do with spirituality, right? It only has to do with spirituality ... But mostly I think it is the spiritual disturbance because we all have weaknesses [disease is spiritual weakness]. (Esculápia)

The individuals are afraid of what happens in psychiatric illness, and when they judge the manifestation of their more eccentric and bizarre symptoms, they are faced with the limits of reason. The symbolic relation is about the weakness that weighs on all human beings. All humans are liable to insanity.

\section{b. The restriction and confusion on spiritual practices with patients}

Even assuming this hybrid nature between the psychopathological and the metaphysical on the disease, and the predilection in the latter, spirituality remains on the condition of being restricted, and its practice veiled in care interventions. Practices, and their intentions in the spiritual realm, were listed in a variety of ways, but reduced to discretion. That is, the individuals assume the need, conceive forms, but do not support their applicability, reproducing again the many contrasts.

[...] In psychiatry, we pray, but sometimes at home because it does not mix. Very mess the patient's head. (Filofrósine)

[...] I know that as soon as psychiatry it is very different from any existing pathology. This I can assure you. Have you seen any psychiatric patients who have healed? No. Now [sighs], it's interesting that some have a more mystical, religious verbalization. Incredible, when they go into outbreak they go straight to this mystical / religious verbalization. (Chrysippus)

Among the professionals, there were those who judged that spiritual care is not due in the psychiatric scenario, justified by the quality of their results. Finally, the meanings that describe a solution to the tension between these limits try to mitigate the appearance of care centered on a spiritual ethic and thus does not convey its essence to the patient.

\section{Faith, belief, religion, spirituality and conflict}

In this last section, the meanings attributed to the different elements that the individuals relate to the experience of spirituality, gather the contrast between the virtuous and the afflictive. These contrasts mark the clash between hope and incomprehension about the moment of life and the idealization expressed by faith or the designation of God.

[...] you really have so much, so you have so much in mind that you think you're going to be able to change the world, right through the know there ... Through your 
belief, through ... Your way of being, in the way you treat, in your ... Everything. Cé is taking so much clucking, né, that speaks: 'pulls life, you no longer believe in anything else' ... Like the loss of a child, for example ... It is a reality [explains the changes between the being and the unbelieving walk motivated from the early death of the son] (Erínea)

Faith is trust and security. But the individual, when he becomes aware of the contrast between what he believes in those who believe in the ideal for which he should be assured in aspects of his life and his actual experience, experiences anguish and anger. It is again the moment to move the limits of reason. There is something hermetic between belief and misfortune, dynamically offering mutual innovations. Belief is a predisposition to save oneself from misfortune, anticipating and preparing the individual for it, because it confronts it by faith, misfortune is the unexpected (un) expected, and by having this quality adaptations are required of the symbolic system of beliefs of the individual that can not measure logic in this conflict process.

\section{DISCUSSION}

Contrary to developments in ${ }^{(2,8,10,23-25)}$ theories, models and instruments that aim to promote the offer of humanized and holistic care to the spiritual needs of users in mental health and psychiatric services, it is reported that this necessity remains neglected $^{(9)}$. The causes described for the fact point to educational problems that do not interfere with the status quo of professional practice ${ }^{(4,8-9,13,26)}$. The attitudes found in caregivers towards this theme are denial ${ }^{(6)}$, disregard ${ }^{(26-28)}$ for lack of knowledge ${ }^{(5,8,13,28)}$, and unavailability ${ }^{(8)}$. Added to these attitudes, feelings of reluctance $^{(6,28)}$, caution ${ }^{(6)}$, and discomfort ${ }^{(25)}$ for the interface of mental health care with spirituality are reported. In addition to the educational boundaries for this relationship, there are also those of research on the scientific difficulty to approach the spiritu$\mathrm{al}^{(3,6-7,25)}$; Finally, the confusion it holds with the phenomena of mental illness ${ }^{(27)}$ and the ethical contours of the profession's limits and professional posture ${ }^{(2,6,10)}$.

Our study, in a special way, offers a response to the complaint against the nature of spirituality studies in the field of Mental Health and Psychiatry nursing because they are more focused on well being than worrying about exploring the attitude of nurses, and the relationship of how their particular beliefs affect practice ${ }^{(8)}$.

In our interviewees, there was a tendency to veil and restrict their views and actions regarding spiritual practices in dealing with patients, and did not delve into what they represent to them. They understand the relevance of spirituality in their lives and their importance to work, but they are, by the way, inhibited in caregiving action when addressing this type of need, and recognize the reductionist character of this attitude. They justify themselves, arguing that the size may be confusing for psychiatric patients; but we find that there is a confusion about the spiritual field for the individuals themselves, spirituality being a dimension conceived of subjective conflicts. Perhaps the documented forgetfulness ${ }^{(5)}$, or tendency to neglect $t^{(5,9,25-27)}$, are the reasons for this fact and we lack to understand how the conflicts of the professionals support this omission and reductionist form.

Spiritual care, in the context of Mental Health nursing, is linked to a person's ethical and life-purpose senses, and serves the quality of the therapeutic relationship. There are those who argue that this is done in a technical way ${ }^{(8,11,26)}$, but another recommendation affirms a better efficiency when it comes from the caregiver's sensitivity 24 to the therapeutic relationship. Our data register phenomena that express the compassionate connection between team and patients; between the team there are particular efforts in assisting them in various dimensions of lack, and keep the mood always positive in unity, and this reflects the ethical-spiritual-symbolic dynamic in the allusion of saving the patient from the evil negativism he faces in the adversities of life and illness. This is done intuitively by team members. Thus, we see the need for education in spirituality that complements the ethics of good human nature and voluntary, which ensures a holistic minimal encompasses ${ }^{(2-3,8-11)}$, for being helpless of its complementary theoretical base.

Paul Ricoeur undertook his ethical analysis ${ }^{(16)}$, in which the symbols of Evil ${ }^{(14,16)}$, received and practiced, met under the design of stain and sin regarding the phenomenon of guilt, hence it presents the practical correlations of the necessity of purification through scavenger and rites of expiatory rites as "restoration of integrity"(16). He concluded that these symbolic forms are indirect expressions of the experience of life in the intermediation of the elements of the cosmos with the experience of the sacred, and he argues that this is the first zone of emergeing from symbols.

In this way, we recover a first ethical and practical sense of the symbolic expressions of our individuals caregivers in psychiatry, and their function to the experiences of life, of which care is part. In looking at the meanings of our individuals, the symbolic Evil becomes present: the evil spirits who operate in sickness; the lack expressed by poverty and the absence of hopeful content and its reflection of despair; the eventualities that provoke the need to overcome the difficult - how to finish the (per) course that leads to the new stage of life; the shock received in personal projects for lack of support; and the evil of death. Evil is all that seems to them to be a cause of suffering, like the failure of projects, of commitment or of surpassing. Overcoming is a drama of events and attitudes responsive to them in a particular historical period of the individual. All this connects to the conflicting relationship with the higher plane of forces, and this is intelligible to the property of the individual's requirement during experience. Everything is procedural and distressing, meaning succeeds experience, never precedes it. Therefore, anguish connects us to the second zone of emergence of the symbol ${ }^{(14,16)}$, the psychological one that uses the Freudian explanation.

From Freud's examination of dreams, and their relation to the formations of psychic sense $\mathrm{e}^{(14,16)}$, the interpretation of the contraposition between desire, censorship, and possibilities of satisfaction in life, emerges the symbol. Freud is useful to us by his longing for the deep sense. 
We find that the talk about the individuals' spirituality expresses how they deal with the preposition of the ideal of life and the frustration with it; with the fear of death and suffering coming from living with her in the professional environment and with mourning; with madness and disease; with lack and despair; with the wear and tear on the hard work and the coexistence with the distressing differences. All these common elements cover, symbolically, the fragility before the transitory ${ }^{(29)}$, and the psychological anguish that this entails. It is against this anguish that faith is called, God, and belief is established. These are intermediaries for overcoming, and for ensuring that they strive above all to dispel anguish - for they quarrel with God, or rely on hope in belief and religion, use the virtuosity of faith as a force and employ rites like the use of an amulet. Freud would say that this is an illusion and that his psychological function is to "exorcise the terrors of nature", "to reconcile men with the cruelty of Fate", "to compensate them for the sufferings and privations" of ordinary civilized life.

The individuals symbolize anguish: they say that they stand, contrast with being near or far (of God or faith), balance-imbalance, strength-weakness, and refer this to fear of failure in the performance of their social functions, or in deadly and limiting experience. Frustration consumes them and exhausts them of forces, it is for transcendence that they discipline a moment of suspension of reason and need for illusion. Illusion is what illuminates - in spite of Freud's metaphysical disbelief, it is the agreement between the overcoming, the fragility, and the limit of tolerance to the maddening reality. This reality, and in its contours of suppressed rational understanding, is the connection between caregivers and the structure of their patients. Both are under the dominion of symbols present in the cultural offer on the transcendent, which guarantees to both, the forms of reorganization of the economy of its psychic forces in front of the afflictive finitudes ${ }^{(16)}$.

Ricoeur's reading of Freudian Illusion ${ }^{(16)}$ concludes that its function is to connect the human being with culture, which, if applied to the comprehension of our individuals' speeches, reveals that their illusions express, in transcendental terms, that which does not fit in understanding of the work environment, which "is a very crazy thing", and therefore not exclusive to the psychopathological framework. Freud himself drew relations of similarities and distinctions between religious illusion and delusion ${ }^{(17)}$, and causes refer to the different conditions of dealing with the unbearable, which is not a psychotic phenomenon, but rather a human phenomenon.

The fact is that, for Ricoeur, the analysis of symbols by the cosmic and psychological perspectives is complementary ${ }^{(14)}$. For him, there is no conflict in the symbol, it is man expressing himself in language, but there are limits pertaining to the hermeneutic school of the symbol, which does not replace meaning but complement his understanding. The cosmology of the sacred and psychoanalysis offers these complements ${ }^{(15)}$. In our case, the cosmology of our caregivers' sacred reflects the dimension of life to which they call the sacred. By psychoanalysis, it is said that they need the sacred to defend themselves from anguish.

Freud probes the territory of the depths, but we still want to take this debate to the territory of the meta-horizon, considering that the literature of Mental Health points out that there is, in the function of symbolization of spirituality, the formation of the meaning and purpose of life. We now analyze what happens between the individual and the everyday events that call for deciding and acting, and for this, we add the participation of Frankl's existentialist analysis(20) to the frame of reference. This "advocates the autonomy of spiritual existence"(20), and uses the virtues of "sense and responsibility"(20). For Frankl, there is a transcendent supra-meaning that interrogates the human being, by which one hopes to "show the character of the duty, or mission, of life and, simultaneously, the character of the response of existence" ${ }^{\prime \prime 20)}$.

Signed in this framework, we can list how the findings behave. For example, one must do something about living with the morbid - with the pain of the loss of the beloved relative; with the hospital morbid; with the coexistence with the poor of health, resources, and reason; joining in hospital work calls for the need to trust that someone greater than the hospital is working on you and perfecting your journey. The individual is required to give meaning to what happens in his life to himself, and to the other besides himself, and that this transcendent encounter is the reason for his freedom and responsibility in the attitude to which he engages in life: whether it be bearing, or surpassing, as stated by Frankl ${ }^{(19-20)}$.

The function of the spiritual responses of research individuals in the categories of what Frankl calls tragic optimism is the transformation of suffering into conquest, guilt into improvement, and death into responsibility ${ }^{(19)}$, and an expression of compassionate love in dedication and empowerment of the potentialities present, but not yet active in the other ${ }^{(19)}$. The caregiver who has healed from cancer cares for the mentally ill who does not impose the threat of infection left by chemotherapy that has weakened their resistance; the same for those who suffered from tuberculosis - symbolic are the ways that lead to work in the psychiatric ward. The individual who reached by the nursing work the condition of professional ascent, of improvement in the condition of life, for being a Christian, expresses the desire to want to speak of God and his love for the sick; who was a heavy-duty driver, now feels like exerting in his performance the function of alleviating the weight of the fellow.

Concluding the analysis of the cosmological, psychoanalytic and existential points of view, complementing the symbolic meaning ${ }^{(14-15)}$, we have seen how the spirituality of the individuals shapes their responses to the limiting events that question the whole foundation of human reason, and perhaps this is the a neuralgic point to discuss the posture of a veiled discourse of individuals towards the spirituality of patients and the management of their needs in this dimension. They touch the limits of the condition of suffering and pain. The sacred, in its nature, has taboo of untouched, saintly, and taking its curtain may perhaps symbolically represent a desecration of itself, the exposition of its own fragility. One must deal with one's spirituality ${ }^{(8)}$ in order to deal with one's patients. It is necessary to know how the human successes are processed in the midst of so many contradictions. 


\section{Limitations of the study}

The scenario is characterized by location, time and sample, and studies are needed in other contexts.

\section{Contributions to the area of Nursing, health or public policy}

The study discusses issues of spirituality, mystified topic in mental health and psychiatry that seemingly is not easily handled by professionals as well as common sense. So, the research lends itself to opening the scene and understanding the professional's perception, highlighting the small themes that appear in the interviews, making possible a naturalistic generalization of data and boosting new research in the area.

\section{FINAL CONSIDERATIONS}

When the symbolic meanings of spirituality and caregivers were investigated in the setting of a psychiatric ward, it was verified how they represent constructions about the evil and the suffering of failure, the anxiety of living together with the morbid and transient, and overcoming the different limiting circumstances of life. These elements express themselves in the bonds with the sacred and reflect the daily experience, as well as help the individual in the balance and the disposition to the performance of the social functions of their lives.
Expressions have revealed how they deal as evil - suffering and frustration, as they do with beneficial practices in resisting opposing forces, and how this converges into an ethical attitude of compassion, or a belief-trust formation within the limits of reason.

All formations represent attitudes of the promotion of good, in the face of the experience of reversing evil, that is, a transformation of the conditions of suffering, guilt and transience into a sublime attitude. Between the attitudes employed, and the deep psychological process, is the moment in which reason is dissociated. One undertakes the proposition of the psychological process that affects the rational limits and expands the force of the individual beyond what is conceivable by the explanation. In this phenomenon, in psychiatry, there resides an equation between caregiver and patient that is the cause that perpetuates a more silent attitude in the discourse on the spiritual needs of the patients of this health condition.

The presence of spirituality in psychiatry was shown by the ethical attitude of the caregivers, but veiled as to meet the patient's need and consider his expression in that sense. This restricts a broader management of the patient's needs, which remains disregarded of his right of expression. Perhaps this is a reflection of the spiritual alienation of the caregiver himself by the combined factors exposed, and by all the training difficulties implicit in the formation process that the area needs, entangled by so many peculiarities.

\section{REFERENCES}

1. Nolan P, Crawford P. Towards a rhetoric of spirituality in mental health care. J Adv Nurs[Internet]. 1997 [cited 2016 Oct 30];26(2):289-94. Available from: http://onlinelibrary.wiley.com/doi/10.1046/j.1365-2648.1997.1997026289.x/epdf

2. Cox T. Theory and exemplars of advanced practice spiritual intervention. Complement Ther Nurs Midwifery. 2003;9(1):30-34 5p.

3. Mohr WK. Spiritual Issues in Psychiatric Care. Perspect Psychiatr Care. 2006;42(3):174-83.

4. Murakami R, Campos CJG. Religion and mental health: the challenge of integrating religiosity to patient care. Rev Bras Enferm [Internet]. 2012 [cited 2016 Oct 30];65(2):361-7. Available from: http://www.scielo.br/pdf/reben/v65n2/v65n2a24.pdf Portuguese

5. Koslander T, Arvidsson B. How the spiritual dimension is addressed in psychiatric patient-nurse relationships. J Adv Nurs [Internet]. 2005 [cited 2016 Oct 30];51(6):558-66. Available from: http://dx.doi.org/10.1111/j.1365-2648.2005.03540.x

6. Lee E, Zahn A, Baumann K. How do psychiatric staffs approach religiosity/spirituality in clinical practice? differing perceptions among psychiatric staff members and clinical chaplains. Religions [Internet]. 2015 [cited 2016 Oct 30];6(3):930-47. Available from: http://www.mdpi.com/2077-1444/6/3/930

7. Eeles J, Lowe T, Wellman N. Spirituality or psychosis? an exploration of the criteria that nurses use to evaluate spiritual-type experiences reported by patients. Int J Nurs Stud [Internet]. 2003[cited 2016 Oct 30];40(2):197-206. Available from: http://www. journalofnursingstudies.com/article/S0020-7489(02)00061-5/fulltext

8. Elliott R. Spirituality, mental health nursing and assessment. J Community Nurs[Internet]. 2011 [cited 2016 Oct 30];25(3):4-10 5p. Available from: http://eprints.hud.ac.uk/id/eprint/13227/1/ElliotpdfArticleSpirituality_3.pdf

9. Ledger P, Bowler D. Meeting spiritual needs in mental health care. Nurs Times [Internet]. 2013 [cited 2016 Oct 30];109(9):21-3. Available from: https://www.ncbi.nlm.nih.gov/pubmed/23550487

10. Stuart GW. Mind to care and a future of hope. J Am Psychiatr Nurses Assoc [Internet]. 2010 [cited 2016 Oct 30];16(6):360-5. Available from: http://journals.sagepub.com/doi/pdf/10.1177/1078390310390363

11. Tuck I, Pullen L, Lynn C. Spiritual interventions provided by mental health nurses. West J Nurs Res[Internet]. 1997 [cited 2016 Oct 30];19(3):351-63. Available from: http://journals.sagepub.com/doi/abs/10.1177/019394599701900306

12. Raffay J. How staff and patient experience shapes our perception of spiritual care in a psychiatric setting. J Nurs Manag [Internet]. 2014 [cited 2016 Oct 30];22(7):940-50. Available from: http://onlinelibrary.wiley.com/doi/10.1111/jonm.12056/epdf

13. Thompson I. Mental health and spiritual care. Nurs Stand [Internet]. 2002 [cited 2016 Oct 30];17(9):33-8. Available from: https:// www.ncbi.nlm.nih.gov/pubmed/12478921 
14. Franco S de G. Hermenêutica e psicanálise na obra de Paul Ricoeur. Edicoes Loyola; 1995. 276p.

15. Ricœur P. El conflicto de las interpretaciones: ensayos de hermenéutica. Buenos Aires: Fondo de Cultura Económica; 2003.

16. Ricoeur P. Freud and Philosophy: An Essay on Interpretation. Motilal Banarsidass Publishe; 2008. 592 p.

17. Freud S. O futuro de uma ilusão. In: Obras psicológicas completas de Sigmund Freud edição eletrônica brasileira. Vol. XXI (19271931). Rio de Janeiro: Imago; 1927.

18. Freud S. O caso Schreber: notas psicanalíticas sobre um relato autobiográfico de um caso de paranóia (dementia paranóides). Imago; 1998. 100 p.

19. Frankl VE. Em busca de sentido. Vozes; 1991

20. FrankI VE. A presença ignorada de Deus. São Leopoldo; Petrópolis: Sinodal-Vozes; 1993.

21. Turato ER. Tratado da metodologia da pesquisa clinico-qualitativa. Petrópolis: Vozes; 2003.

22. Freud S. O Inconsciente. In: Obras psicológicas completas de Sigmund Freud, edição eletrônica brasileira - Vol XIV (1914-1916). Rio de Janeiro: Imago; 2000.

23. Kilmer DL, Lane-Tillerson C. When still waters become a soul tsunami: using the tidal model to recover from shipwreck. J Christian Nurs [Internet]. 2013 [cited 2016 Oct 30];30(2):100-4 5p. Available from: https://www.ncbi.nlm.nih.gov/pubmed/23607157

24. O'Reilly ML. Spirituality and mental health clients. J Psychosoc Nurs Ment Health Serv [Internet]. 2004 [cited 2016 Oct 30];42(7):44-53. Available from: https://www.ncbi.nlm.nih.gov/pubmed/15295917

25. Tokpah MM, Middleton L. Psychiatric nurses' understanding of the spiritual dimension of holistic psychiatric nursing practice in South Africa: a phenomenological study. Afr J Nurs Midwifery [Internet]. 2013 [cited 2016 Oct 30];15(1):81-94 14p. Available from: http://hdl.handle.net/10520/EJC136701

26. McLaughlin D. Incorporating individual spiritual beliefs in treatment of inpatient mental health consumers. Perspect Psychiatr Care [Internet]. 2004 [cited 2016 Oct 30];40(3):114-9. Available from: http://onlinelibrary.wiley.com/doi/10.1111/j.1744-6163.2004. tb00005.x/abstract

27. Pullen L, Tuck I, Mix K. Mental health nurses' spiritual perspectives. J Holist Nurs. 1996;14(2):85-97 13p.

28. Brimblecombe N, Tingle A, Tunmore R, Murrells T. Implementing holistic practices in mental health nursing: a national consultation. Int J Nurs Stud [Internet]. 2007 [cited 2016 Oct 30];44(3):339-48. Available from: http://dx.doi.org/10.1016/j. ijnurstu.2006.07.021

29. Freud S. Sobre a Transitoriedade. In: A história do movimento psicanalítico, artigos sobre metapsicologia e outros trabalhos. Edição Eletrônica das Obras psicológicas completas de Sigmund Freud edição eletrônica brasileira - Vol. XIV (1914-1916). Rio de Janeiro: Imago; 2000. 